\title{
The Impact of the Use of Agricultural Accounting on the Financial Performance of Broiler Industry: A Comparative Evaluation Approach on Broiler Industry in Jordan
}

\author{
Ali Al-Sharafat ${ }^{1}$ \\ ${ }^{1}$ Department of Agricultural Economics and Extension, Faculty of Agriculture, Jerash University, Jerash, Jordan \\ Correspondence: Ali Al-Sharafat, Department of Agricultural Economics and Extension, Faculty of Agriculture, \\ Jerash University, P.O. Box 311, Jerash, Post Code 26150, Jordan. E-mail: alijerash@gmail.com
}

Received: September 11, 2016

Accepted: October 13, 2016

Online Published: November 15, 2016

doi:10.5539/jas.v8n12p164

URL: http://dx.doi.org/10.5539/jas.v8n12p164

\begin{abstract}
The main objective of this study was to introduce a comparative analysis to demonstrate the impact of the use of agricultural accounting on the financial performance of broiler farms in Jordan. Broiler farmers in Jordan constituted the study's population. A sample size of 65 broilers farms was randomly selected. Simple random sampling (SRS) procedure was followed. A structured questionnaire was used to obtain data from the interviewed farmers. Returns, costs (fixed and variable), net income and other related financial items were the main items covered in the survey. Data were collected during the period from March $15^{\text {th }} 2014$ to January $30^{\text {th }}$ 2015. The financial performance of the investigated broiler farms was assessed using financial indicators related to benefit-cost analysis procedure. To achieve study objectives, the Net Present Value (NPV), the Internal Rate of Return (IRR) and the Benefits-Costs ratio (B/C) were used. The sample was divided into two categories, the first category consisted of 33 farmers who were adopting agricultural accounting procedures, and the second category consisted of 32 farmers who were not adopting any agricultural accounting procedures or they were adopting minimum level of these procedures. The results of this study revealed that broiler farms adopting agricultural accounting procedures were significantly higher in their financial performance. The values of the three financial indicators (NPV, IRR and B/C) for broiler these farms were positive, high and acceptable compared to farms without or with minimum level of agricultural accounting procedures. Agricultural accounting procedures keep farm efficient, so it is recommended to introduce proper strategies to improve broiler farmers agricultural accounting skills for Jordanian broiler producers. Also, a vital issue to be taken in consideration is to develop agricultural accounting procedures to be utilized by broiler farm managers or owners. Effective management of a farming operation today requires that farm accounting records be kept and updated so managers can make informed decisions affecting the profitability of their farms.
\end{abstract}

Keywords: agricultural accounting, broiler, financial performance, NPV, IRR, BCR

\section{Introduction}

Agricultural Accounting plays an essential role in the success of the agricultural sector productivity in general and in broiler productivity in particular. The absence of accounting practices in the agricultural enterprisesis one of the most important barriers facing the agricultural sector's ability to take advantage of farm management tools to maximize productivity and improve profitability. Agricultural accounting has attracted less attention from researchers and accounting related agencies (Herbohn \& Herbohn, 2006). Modern agricultural accounting implies change from the traditional historical cost model and, in most cases, requires biological assets to be measured (Elad \& Herbohn, 2011; Lefter \& Roman, 2007). This change has been responsible for the debate on agricultural accounting (Argilés, Garcia-Blandón, \& Monllau, 2011). Undutimi (2013) reported that agricultural accounting modernization considers importance of keeping accounting records by farmers. Also, Yaaghubi et al. (2009) reported that farmers success in managing their agricultural activities implies the use agricultural accounting principles.

Agricultural accounting is a branch of accounting pertaining to agricultural activities in which the three areas of accounting apply; Financial Accounting, Cost Accounting and Management Accounting. Estimation of production costs that have been paid for agricultural products requires the use of Cost Accounting. The provision 
of new data can be obtained from the Financial Accounting. The decision-making process by managers of agricultural enterprises and farmers themselves requires reliance on Management Accounting to get to the right decision. Agricultural accounting is known asa specialist areain the agricultural sector, which recorded primarily financial and monetary transactions in agricultural activities, and classifies these transactions by type, as it is interested in estimating production costs that have been incurred for agricultural products, and then prepare financial reports summarizing these financial and monetary transactions (Yaaghubi et al., 2009).

Farm management methods and tools depended on agricultural accounting considered to be one of the main reasons affecting the financial performance of broiler sector among other livestock enterprises (Mendes et al., 2014). Many researchers considered using a well developed, organized and integrated accounting system in agricultural activities inevitably lead to better farm management and development of work performance (Learning, 1989; Allan, 1994). The presence of accounting procedures in agricultural activities leads to the possibility that the farmers and the decision makers determine the reasons for the failure of these activities with great accuracy compared to the situation with the lack of such a system (Argiles \& Slof, 200; Tonea, 2008). Olsson (1988) pointed to the fact that limited use of accounting procedures in any agricultural activity has a close relationship with limited accounting skills to farmers, leading to a negative impact on the financial performance of this activity. Poppe (1991) and Poppe and Breembroek (1992) explained a variety of reasons that may lead to the failure of the agricultural activity, absence of accounting procedures was the core of these reasons. Bronstein (1995) and Crane and Leatham (1995) considered that the use of sound accounting procedures is one of the most important foundations of the success and growth of any agricultural activity. Yaagoubi et al. (2009) showed that the interest in accounting matters in any agricultural activity is one of the most important determinants of the success of farmers. Ahmed and Zabri (2012) reported that there are shortcomings in the use of agricultural accounting principles as an important tool in farm management especially in small and medium-sized farms in most of the developing countries. A similar conclusion was reported by Poppe (1991). Poppe pointed that most of farmers, accountants and decision-makers in most of developing countries are not paying enough attention to agricultural accounting skills as an essential skills needed for successful farm management.

On the other hand, many studies investigated the importance of the adoption of the agricultural accounting principles in farm activities. Luening (1989) and Allen (1994) mentioned that the use of accounting procedures in agricultural activities led to improved production efficiency in these activities. Streeter (1990) concluded that farmers who use accounting systems in their agricultural activity are with highly effective farm management skills, and therefore are with higher degree of right decision-making compared to those who do not use farm accounting systems. In the same context, Sharma (2012) pointed that rely on effective accounting system in any agricultural activity will necessarily lead to improved productivity and thus profitability of the farm. He also reported that the use of updated and sound agricultural accounting procedures in any agricultural activity will provide the foundations that can be relied upon by farmers to adapt their plans to manage this activity properly.

Identifying the reasons that affect the financial performance of any agricultural sector is a very important issue to judge the feasibility of this sector and the possibility of its development for the better to play its role in food security. The process of identifying the reasons that affect the financial performanceof broiler production sector in Jordan is one of the most important things to be studied and searched. The present study aimed atdemonstrating the impact of the use of agricultural accountingon the financial performance of broiler farms in Jordan by identifying some of the indicators related to this performance.

\section{Objectives of Agricultural Accounting}

Agricultural Accounting is an indispensable tool for farm management. Agricultural accounting is used to measure and record all the consumed agricultural resources as well as the financial transactions in a systematic way that allows the farmer to determine the income derived from his agricultural activity (Agromisa Foundation, 2006). In general, there are three main functions for agricultural (farm) accounting; registration, classification and interpretation of financial procedures in any agricultural activity (Sevilengül, 2008). Agricultural accounting areas are classified, like other areas of accounting, as; financial accounting, cost accounting and management accounting. The presence of differences in economic production areas was with significant impact on the evolution of specific specialization of accounting in each of these areas, e.g. banking accounting, insurance accounting, accounting for building and road construction, industrial accounting, agricultural accounting, hotels accounting, tax accounting and other accounting systems (Zeki et al., 2013). Agricultural Accounting goals can be summarized as follows:

1) Equitable distribution of profits among the partners in the agricultural activity. 
2) Estimation of profit and loss in the agricultural activity.

3) Estimation of tax burden on farmers.

4) Monitor the financial and material resources in agricultural projects.

5) Monitor and control financial movements related to agricultural commodities in terms of quantity and value.

6) Help in adopting preventive measures to counter the risks in agricultural activity.

7) Assist in agricultural projects budget planning.

8) Provide information in order to facilitate transactions between parties involved in agricultural activity (rent, buy or sell activities).

9) Provide relevant information to decision makers for the purposes of determining policies relating to agriculture, income and prices.

10) Provide assistance to agricultural companies and institutions in monitoring the performance of employees and managers.

11) Determine the support prices for agricultural goods that would be subject to a subsidy by the state.

12) Provide information on agricultural projects and agricultural credit institutions.

13) Determine the wages of employees.

14) Provide assistance in the field of education, training and research services related to agricultural activities.

\section{Broiler Sector Injordan}

According to the yearbook of the Ministry of Agriculture (MoA) in Jordan, broiler production sector in Jordan ranked first in terms of the volume of investment compared to other sectors of livestock with more than one billion JDs in 2014 ( $1 \mathrm{JD}=1.4$ USD). Number of broiler farms in the same year amounted to be 1752 farms with a total capacity amount of about 34 million birds per production cycle produced together about 270,000 tonnes of broiler meat and providing $90 \%$ of the country's need of this item (MoA, 2014). Jordan is among the top five Arab countries in production of broiler meat with a consumption at an annual rate of between 25-35 kg per capita (Al-Masad, 2010). Figure 1 shows the development of the quantities of broiler meat produced in Jordan for the period 2010-2014.

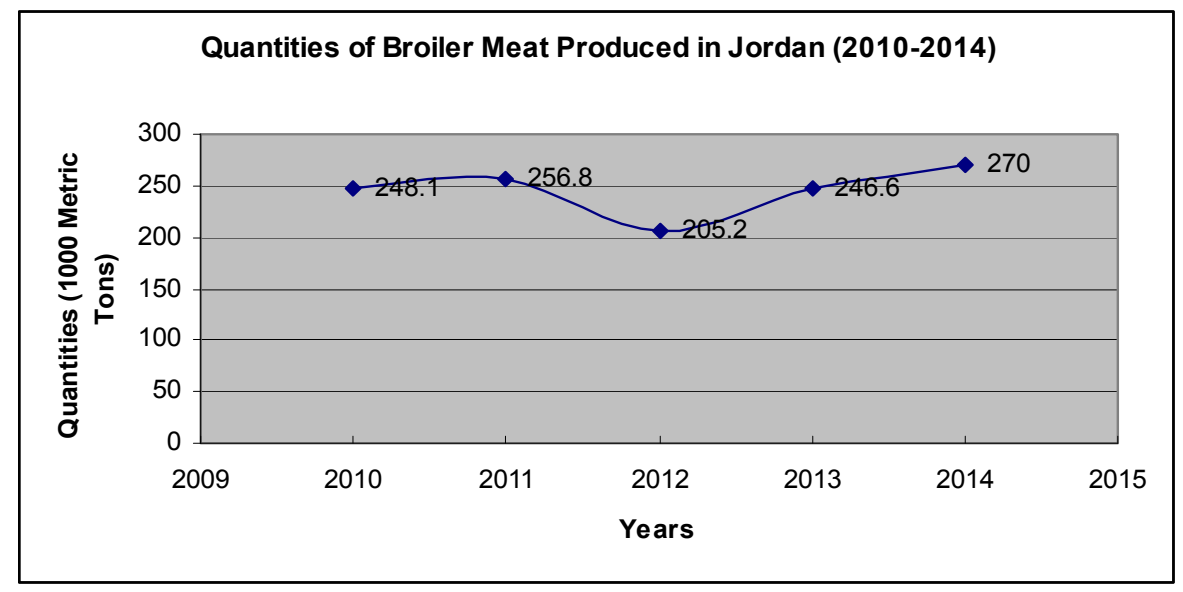

Figure 1. Quantities of broiler meat produced in Jordan (2010-2014)

Source: Author, based on Jordanian Ministry of Agriculture data (2014).

The figure shows that quantities of broiler meat produced in Jordan for the period 2010-2014 were almost the same each year (Except for the year 2012).

Broiler production sector faces in most developing countries, including Jordan, problems such as high and fluctuate prices of production inputs, diseases infection, high transport costs, marketing problems and output price fluctuations costs (Cengiz \& Ceveger, 2003). Despite the existence of the mentioned problems, broiler 
sector in Jordan has witnessed developments in productivity and competitiveness and therefore profitability by focusing on the economies of size which led to the emergence of some large broiler farms in the country. Figueiredo et al. (2006), in a study focused on broiler production methods, pointed that focusing on the economies of size and applying modern accounting and administrative methods in production allowed to achieve a good degree of profitability and led to reduce the possibility of exposure to risks in production.

\section{Materials and Methods}

\subsection{The Sample}

Broiler farmers in Jordan constituted the population of the present study. The sample size was determined based on the following equation (Newbold et al., 2012),

$$
n=\left[\left(p q z^{2}\right) / e^{2}\right] /\left[\left(N e^{2}\right)+\left(p q z^{2}\right) /\left(N e^{2}\right)\right]
$$

Where, $N=$ Population (1752); $n=$ Sample size (?); $p=$ Best guess for prevalence (e.g. \pm 0.50$) ; q=(1-\mathrm{p}) ; z=$ The standardized score (1.645); sample size was determined at a confidence level of 0.90 , so the standardized score is (1.645); $e=$ maximum tolerable error for the prevalence estimate (e.g. \pm 0.10$)$.

Accordingly, the sample size was,

$n=\left[\left(p q z^{2}\right) / e^{2}\right] /\left[\left(N e^{2}\right)+\left(p q z^{2}\right) /\left(N e^{2}\right)\right]$

$n=[(0.25 \times 2.7) / 0.01] /[(1752 \times 0.01)+(0.25 \times 2.7) /(1752 \times 0.01)]$

$n=[67.5] /[(17.52)+(0.675) /(17.52)]$

$n=[(67.5] /[(18.195) /(17.52)]$

$n=[(67.5] /[(1.04)]$

$n=[64.90]$

$n=[65]$

\subsection{Sampling Procedure}

Simple random sampling (SRS) procedure was followed in the present study. SRS is the basic sampling technique where we select a group of subjects (a sample) for study from a larger group (a population). In this procedure every individual in the target population has an equal chance of being part of the sample. This means that a simple random sample of size $\mathrm{n}$ consists of $\mathrm{n}$ individuals from the population chosen in such a way that every set of $\mathrm{n}$ individuals has an equal chance to be the sample actually selected.

\subsection{Data}

A structured questionnaire was used to obtain data from the interviewed farmers. Returns, costs (fixed and variable), net income and other related financial items were the main items covered in the survey. These items were broken down to their corresponding constituents. Data were collected during the period from March $15^{\text {th }}$ 2014 to January $30^{\text {th }}$ 2015. The Jordanian Ministry of Agriculture (MoA), the Jordanian Department of Statistics (DOS), Governmental Agricultural Directorates in governorates, Governmental reports, Research institutions and universities, etc. were the main sources for secondary data.

\subsection{Analysis}

As mentioned earlier, the present study aimed at demonstrating the impact of the use of agricultural accounting on the financial performance of broiler farms in Jordan.

A number of financial indicators are used to assess the financial viability of a project. To achieve its objectives, the present study computed the values of three well known discounted financial indicators; The Net Present Value (NPV), the Internal Rate of Return (IRR) and the Benefits-Costs ratio (B/C). To conduct a comparative financial analysis, the values of these financial indicators were computed for broiler farms which are using agricultural accounting procedures and for broiler farms which are not using any agricultural accounting procedures or using a minimum level of these procedures. Calculations were made on the bases of 12 broiler production cycles.

\subsubsection{The Net Present Value (NPV)}

Sometimes called "net present worth", and it is obtained by subtracting the present value of costs from that of benefits i.e. $N P V=P V B-P V C$ or, mathematically: 


$$
N P V=\sum_{t=1}^{n} \frac{B_{t}-C_{t}}{(1+i)^{t}}
$$

Where, $t=$ individual production cycle; $n=$ number of production cycles over which the project is evaluated; $B=$ the sum of benefits in a given production cycle; $C=$ the sum of costs in a given production cycle; and $i=$ the discount rate expressed as a decimal.

For a project to be acceptable and the investment is to be made the net present value should be positive ( $P V B>$ PVC) otherwise, it should not (Lin et al., 2000).

The above mentioned formula for NPV calculation could be summarized as follows:

$$
N P V=R i /(1+i)^{t}
$$

Where, $t=$ production cycle; $i=$ discount rate; $R i=$ net cash flow.

\subsubsection{The Internal Rate of Return (IRR)}

IRR is that discount rate $i$ for which $P V B=P V C$. This is an efficiency indicator to judge the project. For example, an IRR of $10 \%$ suggests that the proposed investment will generate an average annual rate of return equal to $10 \%$ over the life of the project. When the zero net present value of the project is reached, the discount rate at that value is the IRR of that investment. In other words it is the interest rate that makes the NPV zero (Bruce, 2003, p. 276). If the IRR is less than the costs, the project should be avoided. IRR is calculated by equating the sum of the present value of future cash flow less the initial investment to zero. Or by,

$\mathrm{PV}$ of future cash flows - Initial Investment $=0$; or

$$
C F_{0}+\frac{C F_{1}}{(1+r)^{1}}+\frac{C F_{2}}{(1+r)^{2}}+\frac{C F_{3}}{(1+r)^{3}}+\frac{C F_{n}}{(1+r)^{n}}=0
$$

Where, $C F$ is the Cash Flow generated in the specific period (the last period being n) and $r$ is IRR to be calculated.

\subsubsection{The Benefits-Costs Ratio (BCR)}

$\mathrm{BCR}$ is the ratio of total value of benefits to the total value of the costs. BCR is used to identify the relationship between possible costs and benefits of a proposed project. The project is accepted if the BCR is greater than or equal to one. BCR is calculated by dividing the discounted value of incremental benefits over the discounted value of incremental costs. Or simply by;

$$
B C R=\text { Total discounted benefits/Total discounted costs }
$$

The above mentioned formula could be written as follows,

$$
\Sigma\left(B_{i} /(1+d)^{i}\right) / \Sigma\left(C_{i} /(1+d)^{i}\right)
$$

Where, $B_{i}=$ the benefits of the project in production cycle $i, i=0$ to $\mathrm{n} ; C_{i}=$ the costs of the project in production cycle $i ; d=$ the discount rate; $B_{i} /(1+d)=$ The discounted benefits of the project in production cycle $i ; C_{i} /(1+d)^{i}=$ The discounted costs of the project in production cycle $i$.

Projects with BCR greater than 1 have greater benefits than costs, hence they have positive net benefits. The higher the ratio, the greater the benefits relative to the costs.

\section{Results and Discussion}

\subsection{Sample Distribution}

Sample distribution over the three provinces of the country was based on the relative importance of the total number of broiler farms in each province. The number of broiler farms to be covered in the survey was determined based on comparing the number of farms in each province to the total number offarms in the country. This procedure of sample distribution is followed to insure that all broiler production areas in the country are included in the survey.

To guarantee the achievement of the objectives of the present study, the sample was divided into two categoriesof broiler farms to be interviewed through the entire country. The first group consisted of 33 farms which were adopting agricultural accounting procedures, and the second group consisted of 32 farms which not adopting any agricultural accounting procedures or adopting a minimum level of these procedures. Table 1 shows distribution of broiler farms and sample distribution among the three provinces of the country. 
Table 1. Distribution of broiler farms and sample distribution among provinces of the country

\begin{tabular}{llllll}
\hline Province & $\begin{array}{l}\text { No. of Broiler } \\
\text { Farms }\end{array}$ & $\begin{array}{l}\text { Percentage of } \\
\text { Total (\%) }\end{array}$ & $\begin{array}{l}\text { No. of Interviewed } \\
\text { Farmers }\end{array}$ & $\begin{array}{l}\text { Farms with } \\
\text { agr.acc. Procedures }\end{array}$ & $\begin{array}{l}\text { Farms without } \\
\text { agr.acc. Procedures }\end{array}$ \\
\hline North & 841 & 48 & $(0.48 \times 65)=31$ & 16 & 15 \\
Middle & 683 & 39 & $(0.39 \times 65)=26$ & 13 & 13 \\
South & 228 & 13 & $(0.13 \times 65)=8$ & 4 & 4 \\
\hdashline Total & 1752 & 100 & 65 & 33 & 32 \\
\hline
\end{tabular}

Source: MoA (2014) and researcher calculations.

\subsection{Financial Calculations}

The main financial items related to the financial indicators to be adopted in the analysis of the financial performance of the sampled broiler farmers in the present study include costs, returns and cash flows. These items were determined based on market prices. Table 2 shows costs and returns for farms with agricultural accounting procedures and farms without agricultural accounting procedures (1000 birds on average/production cycle). Table 3 shows cash flow (CF)for farms with agricultural accounting procedures (12 production cycles: PC), and Table 4 shows cash flow for farms without agricultural accounting procedures (12 production cycles) based on data presented in Table 4. Calculations were conducted based on the following market derived facts:

1) An average increase of total variable costs and returns by $1 \%$ and $4 \%$ respectively per production cycle.

2) Mortality rate of $5 \%$.

3) Average selling weight of $1.80 \mathrm{~kg} / \mathrm{bird}$.

4) Average selling price of $1.35 \mathrm{JD} / \mathrm{kgof}$ live weight.

When analyzing the data for both categories of the investigated farms it was noticed that the variable costs were around $13 \%$ higher in the farms without agricultural accounting procedures than those using accounting procedures. The increase was mainly in house preparation, feed costs, vaccination, veterinary services and medicines costs, as well as the other Costs (electricity, water, cleaning and sanitizing ...). These costs were highly related to the absence of managerial records, mainly accounting records. This increase in total variable costs may be attributed to many reasons, one of them could be the absence of the accounting procedures in these farms, mainly the accounting records. The returns were assumed to be equal for both categories for the first production cycle.

Table 2. Average costs and returns for surveyed farms (1000 birds)

\begin{tabular}{lll}
\hline Item & $\begin{array}{l}\text { Cost in Farms with } \\
\text { Accounting Procedures (JDs) }\end{array}$ & $\begin{array}{l}\text { Cost in Farms without } \\
\text { Accounting Procedures (JDs) }\end{array}$ \\
\hline Housing & 2000 & 2000 \\
Labor & 480 & 480 \\
Total Fixed Costs (TFC) & 2480 & 2480 \\
House Preparation (One day old chicks; 0.38 JDs/chick, litter) & 500 & 600 \\
Vaccination, Veterinary Services \& Medicines & 200 & 260 \\
Feed (350 JDs/metric ton) & 1400 & 1500 \\
Other Costs (Electricity, water, Cleaning \& Sanitizing ...) & 200 & 240 \\
Total Variable Costs (TVC) & 2300 & 2600 \\
Returns & 2308.5 & 2308.5 \\
\hline
\end{tabular}

Source: Field survey. 
Table 3. Average CF for $12 \mathrm{PC}$ infarms with agricultural accounting procedures (1000 birds)

\begin{tabular}{llllll}
\hline Production cycle & TFC (JDs) & TVC (JDs) & TC (JDs) & Returns (JDs) & Cash flow (JDs) \\
\hline 1 & 2480 & 2300.000 & 4780.000 & 2308.500 & -2471.5 \\
2 & & 2323.000 & 2323.000 & 2400.840 & 77.84 \\
3 & & 2346.230 & 2346.230 & 2496.873 & 150.643 \\
4 & 2369.692 & 2369.692 & 2596.7479 & 227.0559 \\
5 & & 2393.388 & 2700.6142 & 307.2262 \\
6 & & 2493.388 & 247.321 & 2808.638 & 391.317 \\
7 & 2417.321 & 2465.908 & 3037.822 & 571.914 \\
8 & 2441.494 & 2490.567 & 3159.334 & 668.767 \\
9 & 2465.908 & 2515.472 & 3285.707 & 770.235 \\
10 & 2490.567 & 2540.626 & 3417.135 & 876.509 \\
11 & & 2566.032 & 3553.820 & 987.788 \\
12 & & 2515.472 & & & \\
\hline
\end{tabular}

Source: Calculated by the researcher.

Table 4. Average $\mathrm{CF}$ for $12 \mathrm{PC}$ in farms without agricultural accounting procedures (1000 birds)

\begin{tabular}{|c|c|c|c|c|c|}
\hline Production cycle & TFC (JDs) & TVC (JDs) & TC (JDs) & Returns (JDs) & Cash flow (JDs) \\
\hline 1 & 2480 & 2600.000 & 5080.000 & 2308.500 & -2771.5 \\
\hline 2 & & 2626.000 & 2626.000 & 2400.840 & -225.16 \\
\hline 3 & & 2652.260 & 2652.260 & 2496.873 & -155.387 \\
\hline 4 & & 2678.782 & 2678.782 & 2596.7479 & -82.0341 \\
\hline 5 & & 2705.569 & 2705.569 & 2700.6142 & -4.9548 \\
\hline 6 & & 2732.624 & 2732.624 & 2808.638 & 76.014 \\
\hline 7 & & 2759.950 & 2759.950 & 2920.983 & 161.033 \\
\hline 8 & & 2787.549 & 2787.549 & 3037.822 & 250.273 \\
\hline 9 & & 2815.424 & 2815.424 & 3159.334 & 343.91 \\
\hline 10 & & 2843.578 & 2843.578 & 3285.707 & 442.129 \\
\hline 11 & & 2872.013 & 2872.013 & 3417.135 & 545.122 \\
\hline 12 & & 2900.733 & 2900.733 & 3553.820 & 653.087 \\
\hline
\end{tabular}

Source: Calculated by the researcher.

\subsection{Financial Indicators}

As mentioned in section 4.4, the financial performance of the investigated broiler farms assessed using financial indicators related to benefit-cost analysis procedure. The Net Present Value (NPV), the Internal Rate of Return (IRR) and the Benefits-Costs ratio (B/C) were the three discounted indicators used in the analysis of the data of the present study. The discount rate of $8 \%$ (usually used in feasibility studies in Jordan) was used in calculating the indicators values. Table 5 shows the values of the three financial indicators used to conduct the economic comparison among the investigated broiler production categories.

Table 5. Values of the financial indicators used in the study

\begin{tabular}{lll}
\hline Indicator & Farms with Accounting Procedures & Farms without Accounting Procedures \\
\hline NPV (JDs) & 586.74 & -1779.21 \\
IRR (\%) & 11 & -3 \\
BCR & $(21019.33 / 20450.59)=1.03$ & $(21019.33 \div 22818.54)=0.92$ \\
\hline
\end{tabular}

Source: Calculated by the researcher. 
Table 5 shows that the values of the NPV, IRR and BCR for farms with agricultural accounting procedures were acceptable indicating sound farming procedures including keeping financial farm records and accounting procedures. The NPV for farms with agricultural accounting procedures was positive and acceptable (586.74 JDs) based on average of 1000 birds in the farm. For the same group of farms, the IRR value was $11 \%$ which means that each money unit invested in these farms will provide returns higher with about $11 \%$ above the costs paid. The same group of farms was with a BCR value of 1.03, which is higher than one indicating that these farms were profitable because benefits of these farms outweighed the actual costs of the business. The NPV for farms without agricultural accounting procedures or with minimum level of these procedures was negative $(-1779.21$ JDs) indicating non viable type of business compared to farms with agricultural accounting procedures. The IRR value for these farms confirmed this result (-3\%). This means that each money unit invested in these farms will cause a loss of 3 money units. The same group of farms was with a BCR value of 0.92 , which is lower than one indicating that these farms were not profitable because the costs outweigh the benefits of the business. These results confirm the fact that agricultural accounting is essential if control of the productive process in any agricultural activity is to be achieved. The financial indicators in the investigated broiler farms provide an evidence of how the absence of agricultural accounting procedures could result in higher costs of production mainly in housing costs, feed costs, vaccination, veterinary services and medicines costs, as well as the other costs such electricity, water, cleaning and sanitizing. The absence of accounting records related to these costs make it difficult to control spending on these costs resulting in higher production costs and inefficient control on the used inputs during the production process. As the results of this study revealed, farms with farm accounting procedures that keep records (internal information) are with much better financial performance compared to those who base their performance on familiar knowledge (their own experience), with, little or no concern about systematic record keeping of their activities. In this regard, the revealed results of this study shows the importance of farm accounting to farm business since farms are economic organizations that have to make a broad range of decisions. With the presence of farm accounting procedures farmers acquire sound economic and technical information to make good decisions and implement them properly.

\section{Conclusions}

The present study aimed at assessing the impact of the use of agricultural accounting on the financial performance of broiler farms in Jordan. To achieve the objectives of the study, three well known discounted financial indicators were used; the Net Present Value (NPV), the Internal Rate of Return (IRR) and the Benefits-Costs ratio $(\mathrm{B} / \mathrm{C})$. The results of this study revealed that the financial performance of broiler farms adopting agricultural accounting procedures was much better. The values of the three financial indicators (NPC, IRR and BCR) for broiler farms adopting agricultural accounting procedures were positive, high and acceptable compared to broiler farms without or with minimum level of agricultural accounting procedures. The financial performance of broiler farms not adopting agricultural accounting procedures could be enhanced by presence of proper strategies to improve accounting skills of broiler farmers. Developing agricultural accounting procedures to be used by broiler farm managers or owners is a vital issue to be taken in consideration. Agricultural accounting is very important for broiler business improvements since it is a core determinant of its financial performance. Effective management of a farming operation today requires that farm accounting records be kept and updated so managers can make informed decisions affecting the profitability of their farms.

\section{References}

Ahmed, K., \& Zabri, S. M. (2012). The Uptake of Management Accounting Practices among Malaysian Firms in SMEs Sector (pp. 518-533). Paper presented at the International Conference on Technology Management, Business and Entrepreneurship, Malaysia. Retrieved from http://www.eprints.uthm.edu.my/3437

Allen, R. (1994). Farm potential: High tech leads the average farmer's know-how (No. 88, pp. 26-34). Texas Bank.

Al-Masad, M. (2010). Factors Affecting Profits of Broiler Industry in Jordan: A Quantitative Approach. Research Journal of Biological Sciences, 5(1), 111-115. http://dx.doi.org/10.3923/rjbsci.2010.111.115

Argiles, J., \& Slof, E. (2001). New opportunities for farm accounting. Eur. Account. Rev., 10, 361-383. http://dx.doi.org/10.1080/09638180126640

Argiles, J., Garcia-Blandon, J., \& Monllau, T. (2011). Fair value versus historical cost-Based valuation for biological assets: Predictability of financial informations. Revista de Contabilidad-Spanish Accounting Review, 14(2), 87-113. http://dx.doi.org/10.1016/S1138-4891(11)70029-2 
Bart, G. (2006). Farm Accounting (1st ed., pp. 5-50). Agromisa Foundation, Digigrafi, Wageningen, The Netherlands.

Bronstien, B. F. (1995). Group seeking to bring more farmers into line on financial reporting. Am. Bank, 27, 8-14.

Bruce, J. F. (2003). Investment Performance Measurement. New York: Wiley Press.

Cengiz, Y., \& Ceveger, Y. (2003). A quantitative model to determine factors affecting broiler enterprises. Turk. J. Vet. Anim. Sci., 27, 1201-1205.

Crane, L. M., \& Leatham, D. J. (1995). External equity financing in agriculture via profit and loss sharing contracts: A proposed financial innovation. Agribusiness, 11, 223-233. http://dx.doi.org/10.1002/ 1520-6297(199505/06)11:3\%3C223::AID-AGR2720110304\%3E3.0.CO;2-X

Elad, C., \& Herbohn, K. (2011). Implementing Fair value accounting in the agricultural sector.

Figueiredo, A. M., Santos, S. P., Santolin, R., \& Kings, B. S. (2006). Integration in the creation of broilers in Viçosa - MG: economic feasibility and risk analysis. Rural magazine Engineering, 44(4), 713-730.

Herbohn, K., \& Herbohn, J. (2006). International Accounting Standard (IAS) 41: What Are the Implications for Reporting Forest Assets? Small-scale Forest Economics. Management and Policy, 5(2), 175-189.

Lefter, V., \& Roman, A. (2007). IAS 41: Fair value accounting, Theoretical and Applied Economics, 5(510), $15-22$.

Lin, G. C., Nagalingam, I., \& Sev, V. (1996). Justification of CIM: A guided approach. Proc. of the 4th Int. Conference on Automation Technology, Taiwan (pp. 3-10).

Luening, R. A. (1989). Farms records can improve profitability. Farm Management: How to Achieve Farm Business Goals (pp. 103-112). United States Department of Agriculture, Washington, Government Printing Office, US.

Mendes, A., Gudoski, D. C., Cargnelutti, A. F., Silva, E. J., Carvalho, E. H., \& Morello, G. M. (2014). Factors that impact the financial performance of broiler production in southern states of Paraná, Brazil. Rev. Bras. Cienc. Avic., 16(1), 113-120. http://dx.doi.org/10.1590/S1516 635X2014000100016

Ministry of Agriculture (MoA). (2014). Yearbook of the Jordanian Ministry of Agriculture (p. 62).

Newbold, P., William, C., \& Betty, T. (2012). Statistics for business and economists. Pearson Education (8th ed.). Prentice-Hall International, Upper Saddle River, New Jersey, USA.

Olsson, R. (1988). Management for success in modern agriculture. Eur. Rev. Agric. Econ., 15, 239-259. http://dx.doi.org/10.1093/erae/15.2-3.239

Poppe, K. J. (1991). Information needs and accounting in agriculture. Agric. Econ. Res. Institute LEI, 444, 1-51.

Poppe, K. J., \& Breembroek, J. A. (1992). The assessment of a farm's financial situation with a report writer. Social Housing Magazine, 7, 49-70.

Sevilengül, O. (2008). Financial Accounting (pp. 363-370). GaziKitabevi, Ankara.

Sharma, R. S. (2012). Accounting for Agriculture. International Journal of Recent Research and Review, 2 , 62-66.

Streeter, D. H. (1990). Electronic Information Systems and Farmers Decision Making: Five Case Studies. European Review of Agricultural Economics, 19, 97-113. http://dx.doi.org/10.1093/erae/19.1.97

Tonea, E. (2008). Does the accounting information influence the farm prosperity? Research Journal of Agricultural Science, 40(3), 355-358.

Undutimi, J. D. (2013). Record Keeping Among Small Farmers in Nigeria: Problems and Prospects. International Journal of Scientific Research in Education, 6(2), 214-220.

Yaaghubi, A., Chizari, M., Pezshkirad, G., \& Foeli, S. (2009). Importance of Farm Management Skills From the Viewpoint of Wheat Farmers in Tafresh Township. Journal of Agricultural Economic and Development, 17(66), 99-114.

Zeki, D., Seçkin, A., \& Ayşe, G. (2013). Historical Development Encountered in the Implementation of Agricultural Accounting. International Journal of Food and Agricultural Economics, 1(2), 105-114. 


\section{Copyrights}

Copyright for this article is retained by the author(s), with first publication rights granted to the journal.

This is an open-access article distributed under the terms and conditions of the Creative Commons Attribution license (http://creativecommons.org/licenses/by/4.0/). 